\title{
Turmoils and Economic Miracles: Turkey '13 and Mexico '68
}

\author{
Ilia Xypolia ${ }^{1}$
}

Turkey's demonstrations have been illustrated on the global news for the past few weeks. Wholly unacceptable images of police brutality and government's arrogance have been at the epicentre of the myriad accounts of the events. In the heat of the moment, especially the participants prefer to see the on-going unrest as a revolutionary event. A vague revolutionary fantasy has been filling their heads as they dream of a new beginning for Turkish society. However this paper aims to challenge certain over simplistic and deteriorating myths. In doing so, it holds the argument that the recent events can be best described not as the prelude of a revolution but only as a democratic purge in a developing economy.

Like in every similar case journalists and scholars are tempted to compare ongoing events with glorious previously held ones. A lot have fallen into this trap to link the protests with those that recently took place in Arab countries, the so -called 'Arab Spring'. However, this equivalence is by no means accurate. Still, the ruling AKP party in Turkey not only won the last polls in 2011 but even today enjoys a widespread support in the country. Nevertheless, the most fundamental difference with the protests of the Arab uprising and even the Occupy movement lies in the field of the economy. In the same realm, massive demonstrations and protests of the Los Indignados in southern Europe were mainly caused by the long-standing economic crisis and the neoliberal austerity in rapidly declining economies. While in all these cases from the Mediterranean cities to the Western core of the Occupy movement the young educated middle-class were protesting against their economic suffering, in Turkey the economic growth of the past decade has produced considerable benefits for the population. In particular, the emerging new middle-class in Turkey has seen its living standards rapidly increase during the AKP's time in office. Therefore any comparison between the protests in Turkey and the recent turmoil in Mediterranean and the West lacks a basic understanding of the people's demands.

The central argument that this paper holds here is that in search of historical comparisons the Turkish protests have more similarities with those that took place in 1968 and especially in Mexico in the summer of 1968 than any other case. In July 1968 as the echo from the uprisings in Paris and Prague was fading away, students in Mexico revolted against the government of President Gustavo Diaz Ordaz. ${ }^{2}$ The protests ended with the Tlatelolco massacre in October 1968. Despite their national peculiarities, from a political economy perspective these countries share a lot of common features.

\footnotetext{
${ }_{1}^{1} \mathrm{PhD}$ candidate, Research Institute for Social Sciences, Keele University, UK.

2 King J. (2007) The Role of Mexico's Plural in Latin American Literary and Political Culture. From Tlatelolco to the "Philantropic Ogre". New York: Palgrave Macmillan.
} 


\section{Rising Economies}

The main common denominator in the cases of Turkey and Mexico is their economic performance. Turkey and Mexico are developing countries with dynamically emerging economies. Samuel P. Huntington calls both Turkey and Mexico, along with Russia and Australia, torn countries that have reformed to a 'modern economic system' but have maintained their traditions. ${ }^{3}$ Notwithstanding analyses that could not move beyond the fallacious binary of secularism vs. Islamism have failed to grasp the new economic realities.

Both economies enjoyed a period of growth before the outbreak of the unrests. During the 196os, the high growth of the Mexican economy (graph 1) along with low rates of inflation made observers refer to the 'Mexican Miracle'. Mexico's post-war inward-looking economic development was comprised of a rapid industrialization along with a trade protectionist policy. ${ }^{4}$ During these "golden years" Mexico's economy was industrialized and modernized.

Graph 1: Mexico GDP growth, 1960-19695

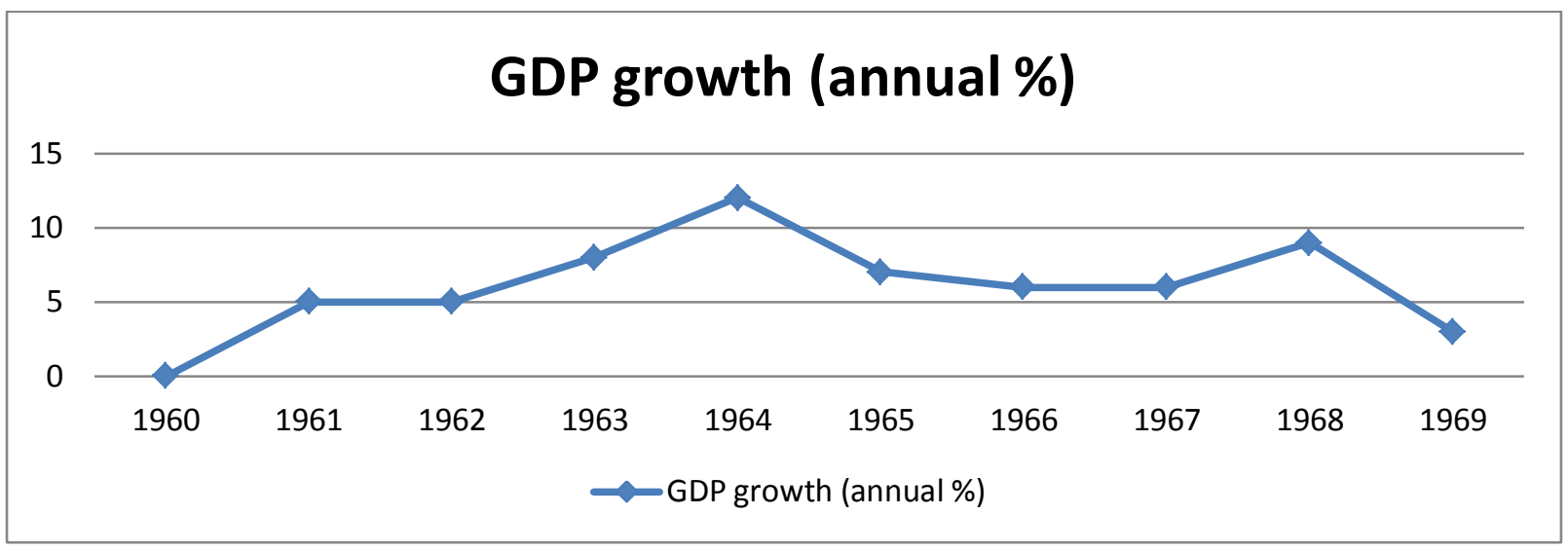

Graph 2: Mexico GDP, 1960-1969 ${ }^{6}$

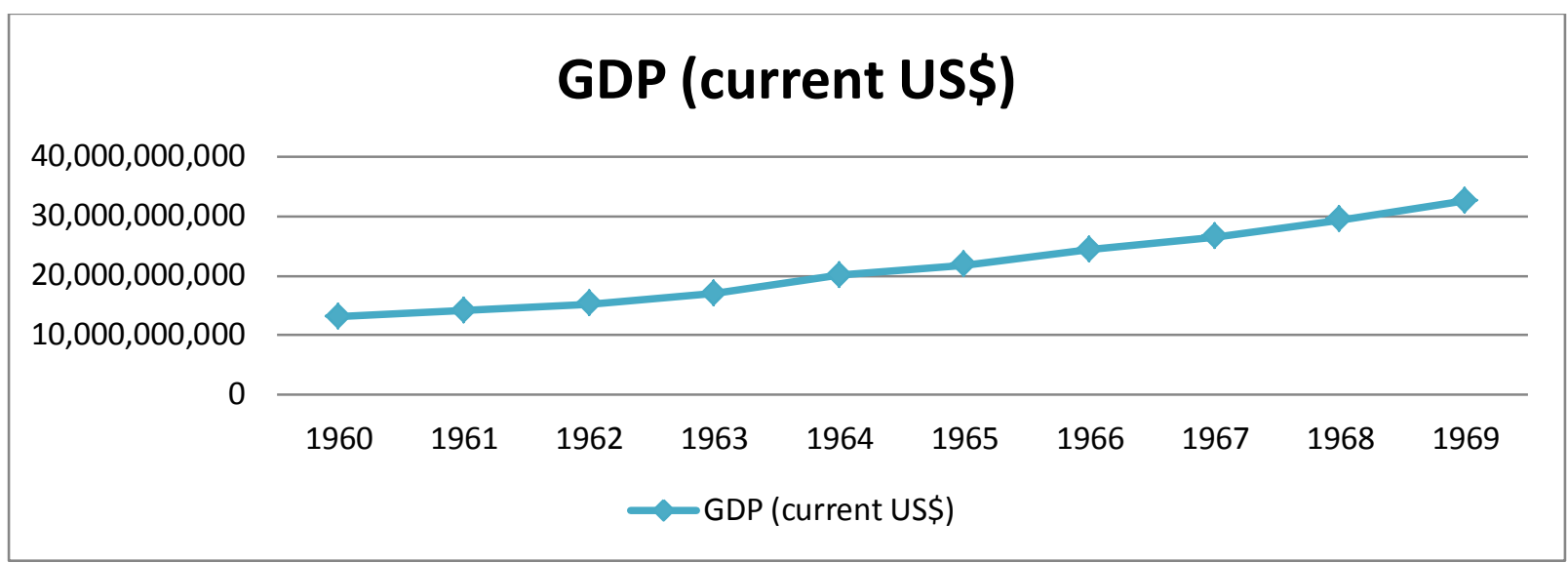

\footnotetext{
${ }^{3}$ Huntington, S., P., (1993) The Clash of Civilizations? Foreign Affairs, 72(3), pp. 22-49.

${ }^{4}$ Lustig, N. (1998) Mexico: The Remaking of an Economy. Washington, D.C.: The Brookings Institution. 2nd Edition.

${ }^{5}$ Compiled on the base of data from the World Bank, http://databank.worldbank.org (retrieved July, 2013)

${ }^{6}$ Compiled on the base of data from the World Bank, http://databank.worldbank.org (retrieved July, 2013)
} 
Turkey has managed to swiftly recover from the 2001 crisis by adopting fiscal and financial reforms under the Ecevit coalition government. ${ }^{7}$ The reforms that were initiated by the minister of finance Kemal Dervis moved forward with the advent of the AKP government. Macroeconomic stabilization and structural reforms resulted in a stable GDP growth up until the outbreak of the global crisis (Graph 4). Turkey succeeded to make her final payment on its IMF debt in May 2013 just few weeks before the outbreak of the demonstrations. ${ }^{8}$ Turkey's economy has performed remarkably well amid a global financial crisis. During this period Turkey has generated high annual growth rates. The good economic performance of the past decade has dramatically improved the income and the living standards of the vast majority of Turkish citizens.

Graph 3: Turkey GDP growth, 2000-2013 ${ }^{9}$

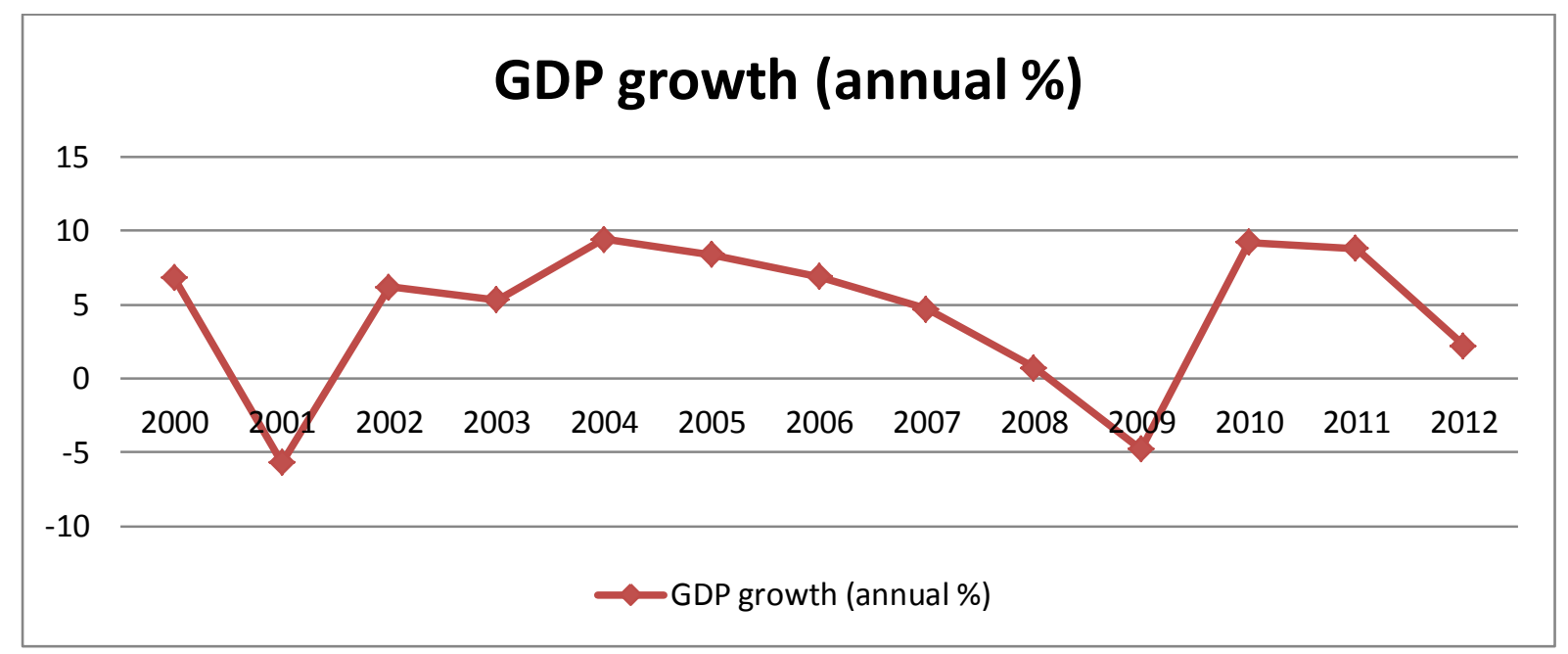

Graph 4: Turkey GDP, 2000-2013 ${ }^{10}$

\section{GDP (current US\$)}

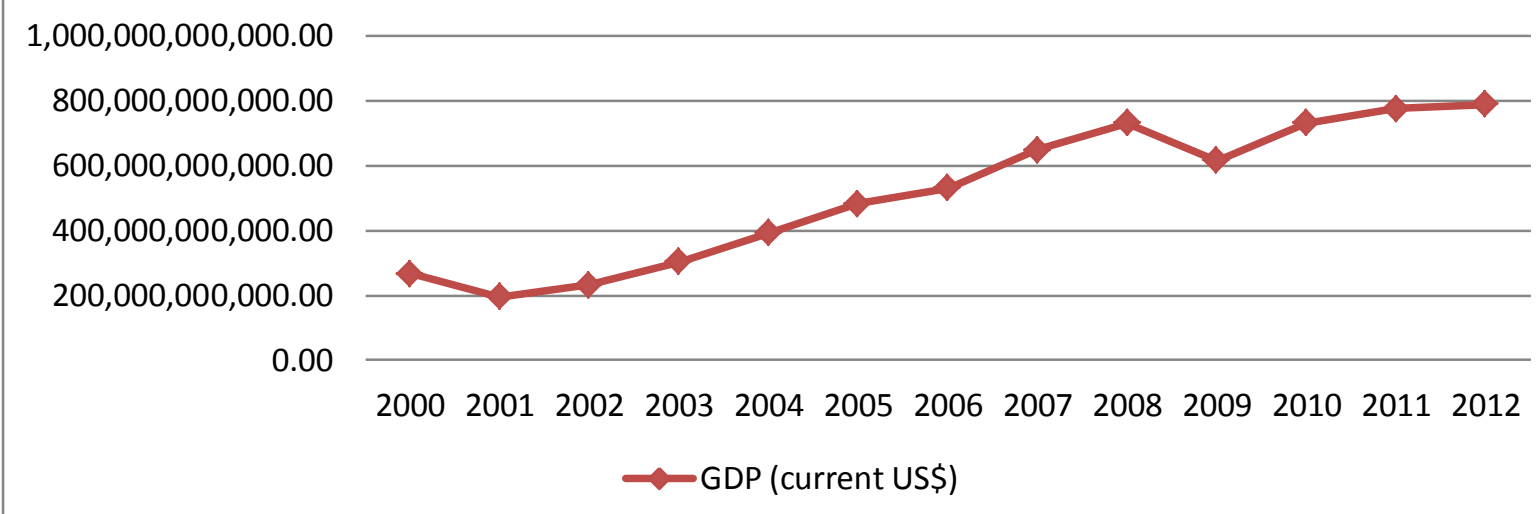

\footnotetext{
${ }^{7}$ European Commission (2009) Growth and economic crises in Turkey: leaving behind a turbulent past? Mihai Macovei . European Economy. Economic Papers. 386. retrieved July 2013 http://ec.europa.eu/economy_finance/publications/publication16004_en.pdf

${ }^{8}$ International Monetary Fund, Press Release, 14 May 2013. http://www.imf.org/external/country/TUR/rr/2013/051413.pdf

${ }^{9}$ Compiled on the base of data from the World Bank, http://databank.worldbank.org (retrieved July, 2013)

${ }^{10}$ Compiled on the base of data from the World Bank, http://databank.worldbank.org (retrieved July, 2013)
} 


\section{Middle Classes and Problems in Democracy}

Against this background, new middle classes have arisen. The new generations of young educated and employed middle class with expanded expectations as citizens constitutes the vast majority of the participants in the protests who aspire to be the agents of change.

The Mexican middle class in the 1960s enjoyed a quality of life unimaginable in previous decades. These children of the Mexican Revolution that now lived in comfort were, for the first time, able to send their own children to university in unprecedented numbers. ${ }^{11}$ Although the economy continued to flourish, social inequality remained a factor of discontent. Moreover, the Institutional Revolutionary Party's (PRI) rule became increasingly authoritarian and at times oppressive.

In the past decade the urban middle class in Turkey has enjoyed unprecedented economic prosperity but it was restricted by authoritarian politics and rigid morality. According to OCED Better Life Index ${ }^{12}$, Turkey has made considerable progress in improving the quality of life of its citizens over the last two decades. In Turkey the Income and Living Conditions have dramatically improved in the past decade. ${ }^{13}$ However, green space is a major issue in a megacity like Istanbul. In Turkey, 33\% of people feel they lack access to green spaces, much more that the $12 \%$ average of OECD European countries. ${ }^{14}$

Though in both cases governments were democratically elected by a high margin, there are structural problems in the democratic system. However despite its outward modernity, Mexico's politics were trapped in another age. The hegemonic party model allowed one party to monopolize power for almost 70 years. ${ }^{15}$ Nevertheless, The PRI enjoyed the popular support and maintained its hegemony during the 1960s. The one-state regime was leaving no political space for a credible opposition.

Though the AKP government has taken important measures towards democratic reform, the electoral $10 \%$ threshold was designed to prevent a proper Kurdish representation in Ankara. The restriction of freedom of speech is a key issue in Turkey illustrated with the tight control of the media, on imprisoning journalists, especially those who express views critical of the authorities on the Kurdish issue. It is indicative that in the 2013 Reporters Without Borders World Press Freedom Index Turkey has fallen on $154^{\text {th }} \cdot{ }^{6}$

\footnotetext{
${ }^{11}$ Loaeza, S. (1993) Mexico 1968: Los Origenes de la transicion, in Semo, I. et al (eds.) La Transicion Interrumpida: Mexico 1968- 1988. Mexico: Universidad IberoAmericana/ Nueva Imagen. Pp.15-48.

${ }^{12}$ OECD Economic Surveys: Turkey 2012

http://www.oecd.org/eco/surveys/OVERVIEW\%20ENGLISH\%20FINAL.pdf

${ }_{13}^{13}$ Turkish Statistical Institute, http://www.turkstat.gov.tr

${ }^{14}$ OECD Economic Surveys: Turkey 2012

http://www.oecd.org/eco/surveys/OVERVIEW\%20ENGLISH\%20FINAL.pdf

${ }^{15}$ For the structural impediments of the democratic system in Mexico, see. Crespo, J. A. (2004) Policy Papers on the Americas: The Party System and Democratic Governance in Mexico - Volume XV, Study 2. Online : http://csis.org/files/media/csis/pubs/ppcrespo[1].pdf

${ }^{16}$ Reporters Without Borders (2013), World Press Freedom Index - 2013, available at:http://en.rsf.org/pressfreedom-index-2013,1054.html
} 
A.K.P., has adopted an increasingly authoritarian attitude that threatens to control basic freedoms of the Turkish citizens. The latest measures that were undertaken by the Turkish government included the restriction of selling alcohol and the kiss in the metro. The decision to demolish one of few green spaces in the City and to build Ottoman barracks was the straw that broke the camel's back. It is worth noting that a lot of analyses fall into the trap of attributing this turmoil only to the long-standing conflict in the Turkish society that has its roots in the late Ottoman era. Unfortunately, these accounts only scratch the surface, as these social cleavages cannot fully explain the dynamics of the recent events.

\section{Dealing with the unrest}

One more common feature is the spontaneous character of the protest. There is also a lack of central leadership. In both cases the protests appear to have spontaneously exploded. These forms of collective action have not been initiated by a clear leadership figure. In Gezi Park the vast majority of the participants were not a member of any political party or association. ${ }^{17}$ The protestors are highly-educated. ${ }^{18}$ Turkey has invested in the educational system in order to strengthen its human capital. ${ }^{19}$ In Mexico also the main protestors were students who were not affiliated with any political party. ${ }^{20}$

The role of women is important in both cases. In the case of Mexico a lot of women participated in leading positions. Actually these protests are now considered as the starting point of the Mexican feminism movements that gained momentum in the 1970s. ${ }^{21}$ The hegemonic and patriarchal model that Erdogan represents has been criticized by Turkish feminist groups. The public sphere is male dominated and it is reflected on the slogans of the resistance. Graffiti and slogans from the protestors often deploy a sexist and masculine language. However, there is an attempt by feminist and LGBT activists to reinvent the 'language of resistance'. Feminist and LGBT activists for instance covered sexist graffiti attacking the Prime Minister. They even wore T-shirts calling to resist without swearing. ${ }^{22}$

The governmental arrogance provided a fertile ground for the protests to gain a momentum. The driving force of both unrests was the aspiration of freedom and the

\footnotetext{
${ }^{17}$ According to a Poll, the $79 \%$ of participants in the Gezi Park resistance were not a member of any political party or association. In the Konda Poll, 4.411 people participated in the resistance on June 6-7, almost in its peak http://t24.com.tr/haber/konda-gezi-parki-anketi-cikardi/231889

${ }_{18} 35 \%$ high school graduates and $43 \%$ university graduates and $13 \%$ a post-graduate degree. Konda Poll for the T24. 4.411 people participated in the resistance on June 6-7, almost in its peak http://t24.com.tr/haber/kondagezi-parki-anketi-cikardi/231889

${ }^{19}$ OECD Economic Surveys: Turkey 2012

http://www.oecd.org/eco/surveys/OVERVIEW\%20ENGLISH\%20FINAL.pdf

${ }^{20}$ Poniatowska, E. (1971), La noche de Tlatelolco. Mexico: Era.

${ }^{21}$ Frazier, L.J. and Cohen, D. (2003), Mexico '68: Defining the Space of the Movement, Heroic Masculinity in the Prison, and "Women" in the Streets, Hispanic American Historical Review, 83:4, pp. 617-660

${ }^{22}$ Korkman, Z. K. and Aciksoz, S. C. (2013) Erdogan's Masculinity and the Language of the Gezi Resistance. Jadaliyya, 22 June http://www.jadaliyya.com/pages/index/12367/erdogan\%E2\%80\%99s-masculinity-and-thelanguage-of-the-gezi [accessed 23 June 2013]
} 
democratic purge. The economies were growing fast and they had created a new middle class with demands of being incorporated to the political processes.

Same as in Mexico, Turkish government attempted to undermine the protestors by arranging demonstrations of their own. In the governmental rallies that were organised, the leaders exposed their unwillingness to compromise with the protestors. President Diaz Ordaz dismissed the public unrest in his national address and even threatened continued violence against any future demonstration of dissent. Aggressive and intimidating public addresses had acted as a red rag to a bull.

Social media in case of Turkey played an important role in the mobilization and the communication of the demonstrators. The Turkish Prime Minister blamed social media as 'the menace to society'. ${ }^{23}$ In the 1960 s, when social media had not penetrated our lives, demonstrators were using more conventional ways and means of communication. President Diaz Ordaz held that the protestors had 'a great capacity for propaganda and dissemination of falsehood and perversity. ${ }^{24}$

Both the Institutional Revolutionary Party (PRI) in Mexico and the Justice and Development Party (AKP) in Turkey acted stubbornly in dealing with the protesters. Governments' initiatives aimed at discrediting the protests. Erdogan warned protesters to leave the Gezi Park and tension rose after Erdogan counter-rally. ${ }^{25}$ President Diaz Ordaz addressing the General Congress of the Union in September 1968 stated that though they had been tolerant until then, they would not continue to permit the violation of the legal order. ${ }^{26}$ The government made the distinction calling certain protestors peaceful while the rest marginal, extremisms and terrorists.

The excessive use of force by the oppressive state apparatus, the police was observed in both cases. In Turkey thousands of teargas and water canon against demonstrators have been reported. In Mexico police used excessive violence in order to control the riots. A report on the brutality of riot control in Mexico it is indicative. Mexican Army units were utilized to assist police and riot police (Granaderos) in breaking up student riots which got out of control at the end of July. ${ }^{27}$

The protests both in Turkey and Mexico were highly influenced by the revolutionary spirit of the time. The Spring of 1968 highly influenced the students in Mexico. Some of the participants in the Turkish demos are Western educated and actually they have been participating in the Occupy movements in London and New York. In Mexico their slogans often referred to the assassination of Ernesto Che Guevara that took place the previous year.

\footnotetext{
${ }^{23}$ Letsch, C. (2013) 'Social media and opposition to blame for protests, says Turkish PM'. Guardian, 3 June http://www.guardian.co.uk/world/2013/jun/02/turkish-protesters-control-istanbul-square (accessed 3 June 2013)

${ }^{24}$ Poniatowska, E. (1971), La noche de Tlatelolco. Mexico: Era. p. 64

${ }^{25}$ Morris, C. (2013) 'Turkey unrest: Mass rally for Erdogan amid new clashes.' BBC, 16 June http://www.bbc.co.uk/news/world-europe-22925619 (accessed 16 June 2013)

${ }^{26}$ Poniatowska, E. (1971), La noche de Tlatelolco. Mexico: Era. P. 52

${ }^{27}$ DIA Intelligence Information Report, Troops Used to Help Quell Mexico City Student Riots, c. August 15, 1968, Confidential. (retrieved July 2013)

http://www.gwu.edu/ nsarchiv/NSAEBB/NSAEBB10/docs/doc04.pdf
} 


\section{Legacy}

To sum up, the driving force behind the unrests both in Mexico 1968 and recently in Turkey is the changing economic conditions of the countries and their middle classes in particular. An improvement of the living standards for the newly arisen urban middle class does not automatically translate into more democratic rights. The demands and the concerns of the protestors showed that this highly-educated new generation feels marginalised and desires more political space that encompasses their interests.

Applying Albert Hirschman's terms in democratic states, dissatisfied citizens could respond to a deteriorating relationship with the government either with exiting or complaining (voice). ${ }^{28}$ The opted voice that citizens have raised could lead to an improvement of the government's performance. What is needed now for the government is to take heed of the protestor's concerns and attempt to accommodate them in a democratic and inclusive manner.

AKP has been in power for over a decade. These protests are a wakeup call for AKP. Politically engaged and vociferous citizens are an asset for the democracy. Democratic reform to incorporate the concerns of the protestors is needed.

Although the protests in Mexico 68 did not lead to any direct political change, they lead to a change of mind-set in the population. The protest was suppressed before this change was brought about. The protests in Mexico succeeded in shaping President Echeverria's political initiatives. ${ }^{29}$ Echeverria's reformism can be attributed to the 1968 events.

Myriad accounts of the current financial crisis and the global unrests lack deep historical and theoretically informed analysis. The gradual resurgence of these phenomena should only be examined in a global economic context. The revolutionary spirit calling for more individual freedoms unleashed and paved the way to the economic neo-liberalism. There is a growing volume of literature that draws a direct linkage between the individualism that was cultivated after the 1968 uprisings and the neo-conservatism neo-liberal reforms that followed that. Now we have to wait to see what these recent upheavals will bring. ${ }^{30}$

\footnotetext{
${ }^{28}$ Hirschman, A. O. (1970) Exit, Voice and Loyalty. Responses to Decline in Firms, Organizations, and States. Cambridge, MA: Harvard University Press.

${ }^{29}$ Shapira, Y. (1977) Mexico: The Impact of the 1968 Student Protest on Echeverria's Reformism. Journal of Interamerican Studies and World Affairs. Vol. 19, No. 4, pp. 557-580

${ }^{30}$ See for example the work of Daniel K. Fletcher.
} 